\title{
EL COMPROMISO BAJO SOSPECHA. DE QUÉ HABLAMOS CUANDO HABLAMOS DE COMPROMISO
}

The commitment under suspect. What we are talking about when we are talking about commitment

\author{
MANUEL VALERO GÓMEZ \\ UNIVERSIDAD DE GRANADA (ESPAÑA) manuelvalerogomez@gmail.com
}

RECIBIDO: 11 DE ABRIL DE 2018

ACEPTADO: 16 DE MAYO DE 2018

RESUMEN: Las siguientes páginas plantean la representatividad ideológica de los textos literarios y, más concretamente, ese concepto tan resbaladizo y confuso del compromiso poético. Porque esta forma ideológica de conciencia que conocemos como literatura, así como cualquier otra, responde a una lógica regida por sus propias leyes de producción y, por tanto, con una normatividad. De ahí que entendamos, precisamente, esta norma literaria como una representación del mundo - deformante y mistificadora- en manos de la fuerza productiva que la segrega. Cuando leemos literatura poseemos la firme creencia de leer nuestras vidas, cuando se trata simplemente de tocar - precisamente eso- nuestras vidas, con las yemas de los dedos, en el espejo de la literatura: leer nuestra explotación mediante el reflejo literario de nuestra explotación. Y en este sentido, el compromiso poético siempre responde a las leyes de producción de la poesía, al mito clausurado de su ilusión normativa. Quizá, si el compromiso poético quiere enfrentarse de veras al horizonte ideológico de producción que le atenaza desde hace siglos, pasa por cuestionar el propio compromiso poético, ponerlo bajo sospecha, hasta alcanzar (como plantea Althusser) un inconsciente a cielo abierto.

PALABRAS CLAVE: compromiso, poesía española contemporánea, norma literaria.

ABSTRACT: The following pages raise the ideological representation of literary texts and, more specifically, that slippery and confusing concept of poetic commitment. Because this ideological form of consciousness that we know as literature, as well as any other, responds to a logic governed by its own laws of production and, therefore, with a normativity. That is why we understand, precisely, this literary norm as a representation of the world -deforming and mystifying- in the hands of the productive force that segregates it. When we read literature we have the firm belief of reading our lives, when it is simply a matter of touching-precisely that-our lives, with the tips of our fingers, in the mirror of literature: reading our exploitation through the literary reflection of our exploitation. And in this sense, the poetic commitment always responds to the laws of production of poetry, to the closed myth of its normative illusion. Perhaps, if the poetic commitment really wants to face the ideological horizon of production that has gripped him for centuries, he has to question his own poetic commitment, to put it under suspicion, until he reaches (as Althusser puts it) an unconscious in the open.

KEYWORDS: commitment, contemporary Spanish poetry, literary norm.

Valero Gómez, Manuel.

"El compromiso bajo sospecha. De qué hablamos cuando hablamos de compromiso".

Kamchatka. Revista de análisis cultural 11 (julio 2018): 395-417

DOI: 10.7203/KAM.11.12299. ISSN: 2340-1869 
Manuel Valero Gómez. El compromiso bajo sospecha...

\section{LA CÁMARA OSCURA DE LA LITERATURA, ¿QUIÉN PAGA LOS CRISTALES ROTOS DE LA INDIVIDUALIDAD HISTÓRICA?}

Hace bien poco y buceando entre la bibliografía con motivo de un congreso reciente, recordamos una afirmación del profesor Juan Carlos Rodríguez que resulta crucial a la hora de valorar -como nos proponemos- la representatividad ideológica de los textos literarios y, más concretamente, ese concepto tan resbaladizo y confuso del compromiso, un "fantasma ya demasiado familiar" (García, 2006: 25). Hacemos referencia, en todo caso, a ese momento de "Juan Ramón o la ciudad de pesadilla (De la Forma como estilización a la Forma como vida)" en el que J. C. Rodríguez (1994, 103-117) explica su asombro ante la "homogeneidad" de la poesía actual: "leído un poema, leídos todos". Aquellas palabras no solo sacudieron nuestros interrogantes a la hora de plantearnos los citados conceptos, sino que poseían (y poseen) un demoledor carácter de síntesis que ataca(ba) directamente el corazón - radicalmente- histórico de la lógica productiva de aquellos discursos que conocemos con el nombre de literatura.

Y bien mirado, puestos a tomar como inicio la homogeneidad ideológica de los textos poéticos modernos (siempre, al fondo, el horizonte de producción dominante), conviene que desgranemos algunas cuestiones introductorias relacionadas con el compromiso poético, tema del que pretenden ocuparse las siguientes páginas. Porque cuando se delata de tal manera la citada unicidad del discurso poético quedan desvelados, principalmente, dos puntos inextricables: que 1) otra manera de producir literatura es posible (al margen de su ahistoricidad, al margen de su sometimiento) en tanto en cuanto 2 ) siempre queda bajo resguardo (sin cuestionar) ${ }^{1}$ su apariencia esencial. En todo caso, urge romper de un solo manotazo el espejo en el que parece mirarse eternamente -porque la literatura siempre se habla a sí misma (Rodríguez, 1994: 37), solo se compromete consigo misma (García, 2006) - por muy halagador y vanidoso que pueda resultar su reflejo (poca broma si se trata de una edición rústica y cubiertas de tapa dura). ${ }^{2}$

Cuando Louis Althusser (1968: 56) explica uno de los puntos fuertes de su "Práctica teórica y lucha ideológica", 3 "el origen de la falsedad de la representación ideológica" [las cursivas no son nuestras], realiza especial incidencia en que "la opacidad de la estructura social hace necesariamente mítica la representación del mundo indispensable a la cohesión social". O dicho de forma sucinta, "la ideología aparece así como una cierta representación del mundo, que liga a los

\footnotetext{
1 Y no se trata de cuestionarse sobre si somos / no somos explotados en la praxis social de nuestra vida cotidiana, en la praxis ideológica de la literatura. Porque viene resultando difícil no reconocerse explotado, a pesar de su telón de acero, entre la miseria del capitalismo avanzado (por recurrir a Jameson) que nos ha tocado por suerte. Otro asunto bien distinto es preguntarse quién y bajo qué resortes jurídicos y morales (contrato social) nos explota. Solo queda remitirse a Terry Eagleton (2011: 16): "Y la última vez que lo vi, el capitalismo parecía estar tan batallador como siempre".

2 Como podrá verse a continuación, no tratamos de acogernos - simple y llanamente- a la definición leninista de la obra literaria como un espejo, harto superada (por otra parte). Más bien ahondamos -precisamente- en que la imagen del espejo es engañosa y, finalmente, incompleta o parcial. Y, tal vez, la conciencia historiográfica (o el compromiso mismo) sea uno de esos reflejos difuminados más comunes y embaucadores que nos ofrece el positivismo. Quizá, recordando ese verso perdido entre las páginas de Un río, un amor de Luis Cernuda, la luz sigue siendo un pretexto de la sombra. Remitimos a "La imagen en el espejo", epígrafe fundamental de Para una teoría de la producción literaria (Macherey, 1974: 120-136).

3 Título original "Teoría, práctica teórica y formación teórica. Ideología y lucha teórica” publicado en Casa de las Américas 34 (1966): págs. 5-18. Citamos de Althusser (1968), traducido del francés por Enrique Román.
} 
hombres con sus condiciones de existencia" (50). Por lo tanto, la problemática estriba en que la práctica social del mundo que conocemos (llamémosle economía, derecho, sociedad o literatura) es una representación artificiosa articulada mediante la ideología -y desde la sombra- gracias a una envoltura mítica. Estos planteamientos conectan directamente con un pasaje de La ideología alemana. Porque detrás del célebre enunciado "no es la conciencia la que determina la vida, sino la vida la que determina la conciencia", ${ }_{4}$ Marx y Engels ponen sobre la mesa un asunto fundamental como la producción de las ideas y las representaciones de la conciencia.

Althusser alude a la "opacidad" de la estructura social (en cuanto a la determinación que ocupan los individuos en una estructura) ampliando así la imagen de "cámara oscura" en la que, según Marx y Engels, dicen aparecer los hombres "invertidos" en su "ideología y relaciones": "este fenómeno responde a su proceso histórico de vida, como la inversión de los objetos al proyectarse sobre la retina responde a su proceso de vida directamente físico". Dando por hecho que la ideología es el único pegamento posible en esta opacidad e inversión de objetos, ¿dónde queda el "proceso de vida real" o el "lenguaje de la vida real"? Evidentemente ocultos tras unas condiciones de existencia y una representación del mundo determinadas. De ahí que el hecho de que nos hayan obligado a pensar fuera de la historia (Rodríguez, 1999a: 46) signifique tanto como admitir (althusserianamente hablando) el paso de la teoría del conocimiento a la producción del conocimiento: 5 de la sumisión ante un mundo dado a la controversia sobre la producción material de ese mismo mundo. Todo este proceso de producción y reproducción precisa de una lógica inmanente como bien puede desprenderse de la explicación que lleva a cabo Marx sobre la praxis de la mercancía.

Y, quizá, ahora tienen mayor interés los matices que hemos advertido más arriba sobre la apariencia de esa representación del mundo producida de antemano. Ya que la ideología -vertida insospechadamente sobre las condiciones de existencia y una artificiosidad mítica- alcanza otros niveles de la (re)producción material6 mediante unas "formas de conciencia" que les otorga un falso aire de autonomía. La cuestión gira, principalmente, en torno a la opacidad necesariamente mítica de la que habla Althusser porque da pie para descender a una de las claves a la hora de explicar ese (y no otro) valor eterno conforme al cual siempre se aferran los discursos literarios (el espejo esencial en el que se mira la literatura). Porque, a final de cuentas, esta forma (ideológica) de conciencia que conocemos como literatura, así como cualquier otra, responde a una lógica (en tanto que es una praxis social) regida por sus propias leyes de producción y, por tanto, con una normatividad, en este caso, literaria (Rodríguez, 1984).

De ahí que entendamos, precisamente, esta norma literaria como una representación del mundo -deformante y mistificadora- en manos de la fuerza productiva que la segrega. (Y ya

\footnotetext{
${ }^{4}$ Que bien resume toda una tentativa de escudriñar aquello que Althusser vería luego en sus Aparatos Ideológicos del Estado (producción y reproducción de la fuerza de trabajo, de las condiciones de existencia).

5 Se trata de considerarlo no como un instrumento, sino como un trabajo (Macherey, 1974: 9-10). En todo caso, descender hasta su especificidad histórica: "La gran novedad de la economía marxista consistía, se ha subrayado en varias ocasiones, en pensar lo social como un modo de producción específico. El trabajo deja de ser una subjetividad o una esencia del hombre: Marx sustituye el concepto de un sobrenatural poder de creación (Crítica de Gotha) por el de la producción vista bajo su doble aspecto: proceso de trabajo y relaciones sociales de producción cuyos elementos participan en una combinación de lógica particular” (Kristeva, 1978: 44-45).

${ }^{6}$ Donde Marx y Engels hablan de religión, moral, metafísica y otras ideologías debe incluirse la literatura.
} 
sabemos de sobra que las ideas de la clase dominante son las ideas dominantes en cada época). Esta perspectiva (ya de por sí compleja por su radical historicidad) adquiere mayor gravedad en el ámbito de la producción del conocimiento, puesto que la norma literaria (que no deja de ser una ilusión) $)^{7}$ lleva hasta el extremo su artificio mítico. Digamos, entonces, que la lógica de la norma literaria manifiesta con mayor virulencia su opacidad en la cámara oscura debido a que responde - con total plenitud- a un sentido vicario de la historia (el humanismo) donde se pliegan en un solo vértice algunos fundamentos nodales de la estética kantiana y la ideología burguesa: la noción de un autor que expresa las regiones más íntimas (una intimidad, claro está, supuestamente libre) de su sensibilidad. O dicho con otras palabras, la cámara oscura de la literatura (con especial hincapié en la percepción que existe sobre el objeto poesía) invierte la naturaleza histórica de su producción por una naturaleza humanista, dejando en manos de la individuación del yo (a través de nuestro inconsciente ideológico, como observó magistralmente el profesor Juan Carlos Rodríguez) un valor (fingidamente) esencial, trascendental y eterno: una mano invisible nos reescribe (Valero Gómez, 2016a: 261-267).

Desde luego que un poema, una novela o una pieza de teatro no son fruto de una intención, sino de unas condiciones de existencia determinadas: allí donde la producción sustituye a la creación. Del mismo modo que, basándonos en Spinoza, la imaginación no escribe poemas como tampoco lo hacen la sensibilidad, la intimidad o la belleza. Porque no dejan de ser el mismo mundo (la representación de ese mundo) en tanto que dado (y no facultades innatas). ${ }^{8}$ Que la literatura se mire en su propio espejo agudiza su coraza mítica, su artificiosidad trascendente, así como la estandarización social de una percepción evolucionista y esencial del discurso literario. Pero, sobre todo, amplía los límites del fetichismo que anida en la propia práctica literaria, ya que (como tanto insiste Marx en la proyección que genera el carácter social del trabajo ante los hombres) ha naturalizado la conciencia historiográfica, uno de los signos visibles de nuestro inconsciente ideológico más importantes en la poesía española contemporánea. Como ya hemos dicho en otro lugar (Valero Gómez, 2016b), la poesía actual se aproxima bastante a un ajedrez asolado donde los jóvenes poetas (como si la edad fuese un valor) juegan sus partidas en el tablero de la página (derrotado desde siempre antes) refregándose en el barro historiográfico hasta más allá de las rodillas.

Por el contrario, y desde hace unas décadas, las turbas y trifulcas a las que acostumbran los poetas no hacen más que demostrar que Marx tenía razón en la segunda de sus tesis sobre Feuerbach cuando asegura que la realidad-poder ("la terrenalidad [sic] de su pensamiento", en palabras del filósofo prusiano) debe demostrarse en la práctica. Mientras que empeñarse en los empujones y codazos tras la ardiente antorcha de la tradición (ese monstruo insaciable de sombra

\footnotetext{
7 Macherey (1974: 21) entiende la norma literaria como una ilusión “doble ideal y mejorado", incluso "sublimación" y "visión desplazada", de la ilusión empírica, en tanto que la crítica 1) se pregunta cómo recibir un objeto dado 2) para después absorberlo según un modelo prefijado.

8 A este respecto, V. N. Volóshinov (2009: 53) realiza un apunte interesante en El marxismo y la filosofía del lenguaje: "La psique subjetiva de un hombre no es el objeto para un análisis científico-natural, como si fuera una cosa o un proceso de la naturaleza; la psique subjetiva es el objeto de un proceso de comprensión ideológica y de una comprensiva interpretación socioideológica. Un fenómeno psíquico comprendido e interpretado sólo puede estar sujeto a una explicación que comprenda factores sociales que determinan la vida concreta de un individuo dado en las condiciones de un ambiente social".
} 
alargada y grandes colmillos llamado el canon, y que nadie sabe bien de dónde ha brotado) significa entregarse a las reglas de juego de la poesía, a sus leyes de producción, a su norma literaria. Que "la disputa en torno a la realidad o irrealidad del pensamiento -aislado de la práctica- [sea] un problema puramente escolástico" (nuevamente Marx). Tal vez, después de lo dicho, se alcance a ver con mayor claridad la homogeneidad de la poesía española contemporánea (y el compromiso como un síntoma de segundo orden) a la que aludíamos al comienzo de estas palabras, ya que el horizonte positivista nos ha hecho creer (a los lectores, escritores y críticos literarios) que la poesía (y la literatura en general) es una verdad "siempre igual" porque "no sólo se nos educa en una concepción tradicional de la literatura, sino que se nos educa simultáneamente a todos nosotros a través de una imagen de la literatura concebida en tanto que tradición" (Rodríguez, 2015: 31).

Así pues, ganando ya el terreno de las conclusiones, puede decirse que aprendemos, leemos y escribimos literatura a través de esa inversión que lleva a término la cámara oscura. O dicho de otro modo, cuando leemos literatura poseemos la firme creencia de leer nuestras vidas (entendiéndolas o realizándonos), cuando se trata simplemente de tocar -precisamente esonuestras vidas, con las yemas de los dedos, en el espejo de la literatura: leer nuestra explotación mediante el reflejo literario de nuestra explotación. Algo así como la individualidad histórica haciéndose trampas al solitario. Aunque también hay quien piensa vivir de espaldas a su reflejo, $l$ 'art pour l'art, como Gustave Flaubert cuando invita a recluirse en el arte porque la realidad es tan horrible que solo se puede soportar evitándola. Pese a todo, ya sea la negación o los cristales rotos, también contamos con el ejemplo de Oscar Wilde, quien no supo entrever que el arte nunca es una verdad igual a sí misma, por más que Dorian Gray escondiera su retrato en el fondo de su dependencia más privada (la idea de belleza en el fondo de su intimidad esencial).

\section{POESÍA, ¡OH DULCE MENTIRA!: EL CÍRCULO DE TIZA Y LA JAULA DORADA}

Será entonces oportuno considerar, a la estela de estos planteamientos, la representatividad y funcionalidad ideológicas de un ámbito tan peliagudo como el compromiso literario. En todo caso, la dificultad a la hora de reconocer aquello que Étienne Balibar y Pierre Macherey tanto gustan en llamar contradicciones internas del discurso textual sigue pasando por aceptar que la literatura solo existe en el espejo de nuestro inconsciente ideológico, solo existe en esa cámara oscura de la que hablábamos. Y, de algún modo, "es justamente el texto quien dibuja sus límites" (Kristeva, 1978: 30). Aunque bien valdría matizar que el límite viene anunciado por su sentido, es decir, "la lógica interna de cada inconsciente ideológico no puede ser si no es interior a su propio proceso histórico de producción” (Rodríguez, 1994: 7-11).

Pero volviendo a los embrollos que causa el proceso de abstracción en la producción del trabajo (en la producción de la vida), el fetichismo literario ha propiciado que tomemos por literatura toda una mitología y, consecuentemente, la literatura es la mitología de sus propios mitos (Macherey, 1974: 64): de ahí el compromiso. O recorriendo el mismo camino desde otro punto de fuga, podría decirse que la normatividad de la literatura (sus propias leyes de producción, según hemos dicho) genera la ilusión del texto como dependencia cerrada, atendiendo a su lógica inmanente y una ficticia conciliación del discurso literario en tanto que discurso literario (como un valor previo, como una sustantividad previa). Cuando, muy al 
contrario, es la ideología misma (mediante su práctica, se entiende) aquello que regula la no clausura, aquello que establece las fronteras entre lo incluido y lo excluido (Žižek, 2011: 36). Renée Balibar (1974) ha denominado "estilo literario", precisamente, a la aparente conciliación entre el lenguaje y sus contradicciones ideológicas en el texto mismo; mientras que, el lenguaje (como el contenido, la forma, etc.), es un elemento -obviamente- constitutivo de esas contradicciones y condición sine qua non para expresar su ilusión normativa, ficcional, mítica y clausurada.

Es decir, como ha leído Macherey (1974: 103-136) en el Lenin crítico de Tolstoi, el texto literario no es tanto la expresión de una ideología como su puesta en escena, una representación de esa ficción que precisa volverse contra sí misma. Y este matiz es primordial a la hora de entender el compromiso, o al menos aquello que pensamos como tal, como una categoría de ese sentido humanista de la escritura como expresión. (Porque, finalmente, remite al laberinto tautológico del artista como creador, el hombre haciendo al hombre, obviando que la literatura exige tantearla desde más allá de su conjetura clausurada). Ahora se alcanza a comprender mejor que alejada de su práctica ideológica, la literatura, pierde toda su fuerza bistórica, dejándose vencer como una problemática puramente escolástica. Sería tanto como decir que el compromiso (en cuanto categoría subordinada que no reproduce más que la supuesta esencialidad de la literatura) no es creación e instrumento del hombre, sino que es el hombre (nuestro inconsciente ideológico) quien habita el compromiso. ${ }^{10}$

Vaya por delante que la noción de compromiso ya está comprometida de antemano: el estilo literario, específicamente del compromiso para este caso, desplaza todas las contradicciones ideológicas a otro terreno, (en nuestro ejemplo) al ámbito del tema y el contenido. Por muy paradójico que resulte (casi una metonimia ideológica o paroxismo esencialista), la categoría literaria de compromiso no compromete (al menos en el sentido radicalmente histórico al que nosotros hacemos referencia). Del mismo modo que la palabra manzana no se come (Volóshinov) y el concepto de perro no ladra (Spinoza). Queremos decir que la cristalización del compromiso como categoría no resulta más que el signo (in)visible de producción de una determinada forma de ser y unas determinadas condiciones de existencia (nuevamente Marx): el compromiso (especialmente) poético es un mito encerrado en la propia mitología de la literatura. Así se entiende que, en cuanto tendencia o escuela, el compromiso siempre remite a un inverso

\footnotetext{
9 Y el estilo "siempre tiene algo en bruto", "es una forma sin objetivo, el producto de un empuje, no de una intención” (Barthes, 2005: 9). Esta visión del mundo que es el estilo posee la funcionalidad de responder -y al mismo tiempo de ser signo visible- a una supuesta representación de esa subjetividad, ya sea de su conciencia real, social, afectiva, cultural, etc. Y así es como la ideología lleva a cabo su secreta tarea de reproducción: mediante el texto el sujeto se hace sujeto, la individualidad se hace individualidad, la historia se hace historia y la ideología se hace ideología. Existe, qué duda cabe, la urgencia de separarse de la "imaginación creadora", "hay pues que volverse hacia lo invisible dentro de la libertad poética", "para alcanzar en su noche el origen ciego de la obra" (Derrida, 1989: 16). Y más que nunca, la opacidad de aquello que conocemos como escritura "se hunde en su propia representación" (92) en tanto en cuanto "el texto se plantea en lo real que lo engendra" -que lo reproduce, valdría la pena matizar- hasta "hundirse en una fantasmagoría subjetivista" (Kristeva, 1978: 10).

10 Nos servimos de la brillante inversión de términos que lleva a cabo Lacan a partir del lenguaje como casa del ser heideggeriano (Žižek, 2001: 17-78).
} 
(Rodríguez, 2002: 53).11 Es decir, el espejo en el que se miran los poetas (ya sea mediante una denuncia o una lacónica elegía) devuelve -Narciso arrodillado frente al estanque- una imagen clausurada y mítica de la poesía como ente autónomo, la imagen que el positivismo ha hecho llegar hasta nosotros (mediante la escolástica y alejados de la práctica social de la literatura). ${ }^{12}$

Aquí se encuentra la pieza nodal de esa dulce mentira que conocemos con el nombre de poesía. Dado que hemos heredado ${ }^{13}$ unos supuestos que en la actualidad parecen inamovibles, ya que desde el siglo XVIII pensamos el arte mediatizados por la absurda existencia de no sé qué naturaleza humana (Hauser, 1976 (II): 326-327), conviene poner bajo sospecha la idea de compromiso (y, más concretamente, poético) con el fin de -alguna manera- (re)pensar la literatura. Porque la mitología tradicional del género (García Montero, 1983: 7), tristemente, ha convertido en incuestionable la sacralización del yo poético y su, tan inherente como falso, carácter de sinceridad y expresión propias. Que viene a echar más tierra sobre el soterramiento de la poesía, disciplina tradicionalmente reservada (por encima de todas) al deleite del gusto y la expresión de los más nobles sentimientos del espíritu humano (nótese la ironía), en su falsa mortaja trascendental, esencial y autónoma. Después de tanto esfuerzo de Benedetto Croce por aislar el arte como actividad libre no debe olvidarse que hacer pasar la estética por una ciencia de la expresión sensible y afectiva -a la luz de lo expuesto hasta ahora- resulta tanto como olvidar que los sentidos también tienen historia, que los sentidos también son una práctica social y la estética (como la ética) también esconde una práctica ideológica.

Digamos que la estandarización de la naturaleza ideal del arte, que viene de la mano del siglo XIX, ${ }^{14}$ ha propiciado la creencia absoluta a la hora de separar la ética de la estética: una cosa son los textos (la literatura) y otra bien distinta la moral o actitud del poeta (la vida). Y el compromiso poético juega aquí un papel fundamental. Porque ya se ha dicho que asumir el compromiso poético como categoría (tendencia, escuela o corriente) refuerza su contrario como

\footnotetext{
11 Pierre Macherey (1974: 22-41) va más allá cuando establece que al despejarse la ilusión normativa que sostiene en pie toda obra (y el compromiso es un oasis dentro del espejismo literario) desaparece, al mismo tiempo, su falsa idea de unidad. Un determinismo que le otorga, principalmente desde la crítica literaria, una necesidad que reconstruye una problemática (de principio a fin y desde su anverso hasta su reverso) bajo su fachada de linealidad y evolución sostenida. Esta sustitución de una imagen clausurada de la obra por una imagen abierta arroja luz sobre la afirmación del libro como un artificio, nunca como una realidad o una experiencia.

12 En cualquier caso, se trata de vencer la servidumbre de la literatura, el espesor de la historia que "la nueva positividad de las ciencias de la vida, del lenguaje y de la economía”, quizá perfeccionada por el capitalismo avanzado, encuentra su "correspondencia con la instauración de una filosofía trascendental" (Foucault, 1971: 239).

13 Un término menos inocente que la alegórica pasividad que sugiere, porque -quizá- la violencia más descarnada se halla tras esa misma inocencia invisible de la ideología.

14 Puede decirse, citando a Philippe Sollers, que el nacimiento consciente del concepto de literatura es -en gran parte- inexplicable para nosotros.
} 
un idealismo de partida.15 Mantenerse en el terreno histórico real tiene como principal consecuencia sajarle las bridas a la poesía, sajarle las bridas al compromiso. Al mismo tiempo que, y de un solo golpe, bajar a los poetas de los altos cielos del parnaso hasta hacerles ver que han vivido refugiados en una jaula dorada más que en una torre de marfil. ${ }^{16}$ Allí donde, recurriendo a la imagen brechtiana, la concepción autónoma de la poesía parece empujarnos de un lado a otro del círculo de tiza, ${ }^{17}$ como singular escenario posible donde dos arteros extremos (puro/impuro, forma/contenidos, íntimo/privado) enmascaran en el discurso poético la libertad de un sujeto que piensa expresar su intimidad más privada (García, 2006: 27).

A fin de cuentas, y hacemos balance sobre lo andando, ya no se trata de comprometerse poéticamente con el compromiso porque esa misma postura exige un contrario adánico (una noción de descompromiso ajena a la pesadilla histórica del yo). La "igualdad formal" del capitalismo ${ }^{18}$-señala Lukács (1975: 22-23) en su Historia y conciencia de clase- provoca que el "conocimiento de la sociedad como realidad [representación del mundo dada] no es posible más que sobre la base del capitalismo". O, desciendo otro peldaño en nuestra explicación, el compromiso siempre responde a las leyes de producción de la poesía, al mito clausurado de su

15 El reflejo (siempre parcial o incompleto) devuelve su producción material al espejo esencial de la literatura, ya sea bajo el abrigo de la vox auctoritas (la legitimación social y capacidad moral otorgada a la figura de escritor, llevando a nuestro terreno un término del Derecho Romano) o el amparo de una categorización (artimañas del positivismo). Aquí se encuentra la distancia existente a la hora de explicar la práctica literaria partiendo de las formaciones ideológicas implícitas en su práctica material. Y sale al paso una referencia encontrada recientemente (preferimos no citar la fuente) donde se especifica El Cantar del Mio Cid como poesía comprometida, lo cual viene a corroborar aquella vieja afirmación de Benjamin (a propósito de un poema didáctico de Brecht) en la cual dice que citar un texto implica interrumpir su contexto. O visto de otra manera, esa imagen eterna del pasado (nuevamente Benjamin) a la que nos dirige el historicismo, ese continuum de la historia: tanto como decir que siempre nos espera todo el pasado por delante.

16 Tomamos el término jaula dorada de un momento clave de la Historia social de la literatura y del arte de Arnold Hauser (1976 (III): 27). A propósito de la apropiación de la burguesía del l'art pour l'art, Hauser emplea esta metáfora para explicar la "alta categoría" que adquiere el artista a raíz de la exaltación de la naturaleza ideal del arte hacia el siglo XIX. Parece evidente que este concepto no es de ningún modo inocente y pretende ser envés de la torre de marfil, manera más usual y aceptada que se conoce para denominar, precisamente, ese refugio intelectual e íntimo de los poetas, su taller literario-espiritual. Pese a ser una referencia que se remonta a los orígenes de la cultura occidental, gran culpa de esta cristalización terminológica, como acabamos de señalar, se debe a los esfuerzos realizados por los escritores durante el siglo XIX (son célebres las citas de Flaubert y Rubén Darío) con el objeto de consolidar el arte como una entidad autónoma ampliando los límites de la expresión libre e innata alcanzados un siglo antes. Buena parte de los debates literarios del siglo XX asumen como premisa la torre de marfil (actitud moral y ética de los escritores, su mala conciencia ante los horrores de la historia -que no es igual a decir ante los horrores que cometemos los hombres-, etc.) y, en consecuencia, el compromiso. En todo caso, y como ya matizamos en el cuerpo del texto, existe un abismo entre considerar (y que los escritores mismos consideren) la torre de marfil como lugar propio y sustantivo del poeta (en cuanto que supone una decisión libremente tomada) y empezar a hablar de jaula dorada (en tanto que simboliza el encierro del yo-poético entre los barrotes áureos de una imagen ideal de la literatura). Como veremos a continuación, esa promesa rota de la literatura nos empuja -a través de nuestra práctica ideológica, a través de nuestra vida cotidiana- a lo largo y hondo de ese abismo.

17 Hacemos alusión a la pieza teatral de Bertolt Brecht titulada El círculo de tiza caucasiano (1951). La trama aborda la disputa entre dos koljoses (granjas colectivas de la Unión Soviética) por la posesión de un valle georgiano. La Comisión de Reconstrucción Soviética será la encargada de decidir entre la granja que abandonó las tierras y aquella que se ocupó, posteriormente, de su cuidado. Un cantor, mientras tanto, cuenta una larga parábola sobre la pugna entre dos madres (biológica y adoptiva) por un niño. Ante la incapacidad de saber quién es la verdadera madre, el juez Azdak obliga a las madres a realizar la prueba del círculo de tiza.

18 Y recordará el lector que empezábamos estas palabras hablando sobre la heterogeneidad de la poesía española contemporánea: "leído un poema, leídos todos". 
ilusión normativa, como cualquier otra categoría afín a la práctica ideológica de nuestra vida cotidiana. ${ }^{19}$ Porque, según ha sintetizado lúcidamente el profesor Miguel Ángel García (2015: 232), "la idea de un compromiso del escritor es un producto histórico de la ideología literaria burguesa". Es decir, "el compromiso no es algo que tú eliges, sino algo que ineludiblemente te ha elegido a ti" (Rodríguez, 2002: 54), ya que la funcionalidad del texto siempre está viciada por la "construcción del yo-soy histórico bajo la forma de un yo poético que no existe fuera del poema sino sólo en su interior" (55). La única salida posible, como decíamos al principio de estas palabras, es romper de un solo manotazo el espejo en el que se mira la literatura. Desarticular, en cualquier caso, la lógica productiva que une el capitalismo con la vida ${ }^{20}$ bajo su promesa de subjetividad y expresión sinceras: $i d$ est, pagar los cristales rotos de la individualidad histórica. Solo saliendo de nuestra jaula dorada, caminando fuera del círculo de tiza, seremos capaces de romper con esa imaginada posesión de la literatura (la poesía frente a la vida) hasta preguntarnos -como Pasolini- para qué sirve la luz.

\section{UN INCONSCIENTE A CIELO ABIERTO: DEL MITO A LA NORMALIZACIÓN DEL COMPROMISO}

A estas alturas de la historiografía poética tradicional parece evidente que el compromiso es una moneda de uso común en el libre mercado literario, siempre a caballo entre la inflación nominal y el crac estético. Sin embargo, la masificación, la miopía crítica y el aceleramiento historiográfico que vive -en la actualidad- el género (Valero Gómez, 2016b: 12-16) puede que hayan impedido razonar, entre la maleza del bosque poético, que (precisamente) el compromiso literario es una marca (tan histórica como escolástica) relativamente nueva. Y no andan desencaminadas algunas voces que apuntan hacia la filosofía existencialista como procedencia directa del compromiso, puesto que comúnmente se considera la hipótesis trazada por Jean-Paul Sartre en Qu'est-ce que la littérature? (1948) como armazón teórico de tal concepto, cuando no su definición última.

A este respecto, son interesantes las críticas que Adorno dirige contra el teatro de Bertolt Brecht y el propio Sartre en su conferencia radiofónica titulada "Compromiso o autonomía artística". ${ }^{21}$ El filósofo alemán comienza su discurso señalando una premisa fundamental cuando asegura que "desde que Sartre escribió Qu'est-ce que la littérature?, se discute menos sobre literatura comprometida y autónoma". En cualquier caso, Adorno apunta dos cosas importantes según ese momento decisivo (1962) para la formación y desarrollo del concepto que tenemos entre las manos: 1) la publicación del manifiesto sartreano zanja (dentro de los límites que marcan unos conceptos prefijados) las polémicas que hasta ese momento discuten el papel del artista en la historia, ya que 2) se ha instaurado definitivamente -toda vez cerradas (aparentemente) dichas porfías- la "polarización" entre compromiso y autonomía. Pensemos que la primera mitad del siglo XX, hasta donde alcanza cronológicamente el libro de Sartre, se pone sobre la mesa este

\footnotetext{
19 Nótese aquí, en nuestras nucas, el aliento kantiano y su ideología operativa de la vida cotidiana.

${ }^{20}$ La complejidad de esta problemática, como venimos sosteniendo, radica en que identificamos el capitalismo con la vida como única realidad posible debido a una lógica productiva tan inmanente como oculta (Rodríguez, 2013: 52-59).

21 Pronunciada el 18 de marzo de 1962 en Radio Bremen y publicada en Die neue Rundschau (año 73, núm. 1, 1962). Nos servimos de la traducción española que aparece bajo el título "Compromiso" en Adorno (2009).
} 
debate con un telón de fondo muy determinado: las dos guerras mundiales y, entremedias, el enfrentamiento bélico español secundan las orientaciones impuestas en el Primer Congreso de Escritores Soviéticos, los dos Congresos de Escritores Antifascistas y la escalada de posiciones de los surrealistas.

Una de las claves en las críticas de Adorno (2009: 394) se encuentra en que, como asegura el filósofo, "no se pueden separar los carneros de Sartre y las ovejas de Valéry". Es decir, "la tensión que el arte ha vivido" se "desvanece en estos dos polos", puesto que "cada una de las dos alternativas se niega a sí misma al mismo tiempo que a la otra". Desde luego que "la controversia sigue siendo tan urgente" porque "hay dos posturas frente a la objetividad" que "se hacen la guerra, por más que la vida intelectual las exhiba en una falsa paz". Siendo válidos estos planteamientos e incluso concomitantes con algunos expuestos aquí, debemos superar las apariencias y pasar -pues- a preguntarnos qué significa, para Adorno, esa objetividad a la que se enfrentan el compromiso y la autonomía. Si bien esta falsa polarización (donde los dos extremos se necesitan) coincide con la clausura mítica de la obra mediante la ilusión normativa, su vinculación se desvanece si descendemos hasta el determinismo que condensa la raíz de su planteamiento.

Porque cuando Adorno apuesta por un arte autónomo que no sea incompatible con el carácter comprometido está cediendo a la presión kantiana de la "razón autónoma", o así se entiende cuando insiste en la autoridad de la industria cultural, la resistencia ante el curso del mundo como única actitud posible y la naturaleza sociopolítica del arte. Y no se trata solo de que Adorno se cierre en banda a la hora de escribir la palabra ideología, dado que con el diálogo compromiso / autonomía pretende llevar a cabo una traslación del binomio teoría / praxis. Tiene que ver -más bien- con la esencialidad que deposita en su idea de sociedad y la crisis de la racionalidad (igual que Sartre) que valora con motivo de la segunda gran guerra. O dicho de otro modo, y retrocediendo unas líneas, Adorno no piensa fuera del círculo de tiza: se sitúa a medio camino entre la teoría del conocimiento y la producción del conocimiento. Sería tanto como advertir que la unidad bistórica que pretende entre la teoría y la praxis requiere concebirse fuera del contrato social (círculo de tiza), más allá de una percepción previa del ser humano sujeta a unas cualidades características (libertad, razón, etc.). ${ }^{22}$

Volviendo a Qu'est-ce que la littérature?, la noción sartreana de engagement establece claramente como tarea para el escritor contemporáneo su propia responsabilidad social, puesto que "el escritor no tiene modo alguno de evadirse" (Sartre, 1976: 10). Pero como acabamos de ver gracias a la crítica de Adorno, las posiciones de Sartre alimentan la dicotomía compromiso / autonomía desde el mismo momento en que el compromiso descansa sobre un voluntarismo netamente

\footnotetext{
22 También puede hallarse explicación gracias a la citada imagen brechtiana del círculo de tiza. En sus Escritos sobre teatro, Brecht (1970) se ocupa extensamente de la pieza a la que aludimos en su epígrafe "Para El círculo de tiza caucasiano" (80-103). De hecho, deja bien claro que uno de sus propósitos a la hora de plantear su procedimiento dialéctico es establecer un escenario invadido por la contradicción. Solo que no se trata de cuestionar (a grandes rasgos) una diatriba general, más bien consiste en descender hasta el caso concreto a cada lado del círculo, hasta la terquedad de su postura. El escritor alemán dice lo siguiente en sus anotaciones a la obra: "Mientras más defiende la vida del niño, Gruche [la ayudante de cocina que rescata a Michel, hijo del gobernador Georgi Abachvili] pone más en peligro la suya propia; su productividad la conduce hacia la autodestrucción". Como veremos a continuación, cosa similar ocurre con el ejercicio de la poesía y su (en apariencia) inofensiva individuación.
} 
moral que obtiene su desdoblamiento en la encrucijada responsabilidad / irresponsabilidad (García, 2006: 27). Podría afirmarse, finalmente, que la propia noción de compromiso literario ya nace corrompida por la ahistoricidad humanista de la ideología burguesa clásica. De ahí que si pasamos a considerar qué entendemos actualmente por compromiso literario (y yendo más allá, exclusivamente poético) tengamos que andar con cuidado a la hora de valorar algunos estigmas y menoscabos que han acompañado su propia estandarización en la poesía española contemporánea.

Como ya señaló J. Lechner (1968: 9-10) en su trabajo fundacional, el compromiso "suele evocar generalmente una actitud crítica, inconformista, adoptada casi siempre por escritores pertenecientes a la izquierda política", pero no olvida que la derecha y el fascismo tienen sus propios allegados. Del mismo modo, el realismo socialista ha sido una de las piedras angulares quizá, principal obstáculo- en los vaivenes que ha sufrido el tema a lo largo del siglo XX. (Y mucha culpa de ello, por cierto, tiene aquello que podríamos denominar -sirviéndonos de Engels- como marxismo vulgar). De cualquier manera, y como veremos en las próximas páginas, el concepto de compromiso continúa siendo un asunto espinoso a tenor de la pervivencia de algunas complejidades que ya anunció desde tan lejos el propio Lechner.23 Como también puede verse en las advertencias que figuran en buena parte de los estudios, más o menos recientes, sobre el compromiso.

Pero, descendiendo a nuestro terreno, la cuestión se vuelve más intrincada y continúa hospedada en esa imagen (casi) inamovible que tenemos sobre la poesía. Antes y después de convertirse en pesadilla estética, parece indudable que la tesis de engagement posee una influencia decisiva en la instauración del realismo histórico (o social) como tendencia dominante desde los postulados de Castellet en Veinte años de poesía española (1960) y ese capítulo de cierre que significó Poesía social española contemporánea de Leopoldo de Luis (1965). Asumir, por parte del escritor, su responsabilidad histórica (como así quería Sartre) era dar carta blanca al encierro del intelectual en su jaula dorada. Tanto como ignorar que los intelectuales no son los representantes de una continuidad histórica no interrumpida, más bien heredan unas categorías intelectuales preexistentes (Gramsci, 1977: 28-29) jugando un papel decisivo como fabricantes de la historia. Esta perspectiva moral del compromiso, ajena a su propia normatividad literaria, engarza con los "prejuicios" sartreanos (Lechner, 1968: 15) hacia la poesía y sus posibilidades comprometidas: allí donde asoman las costuras kantianas de su propuesta. "Los poetas no hablan", dice Jean-Paul Sartre (1976: 49), "tampoco se callan: es otra cosa". Verdaderamente, "esa otra cosa" que -para el filósofo francés- es la poesía (frente al teatro, la narrativa y el ensayo) acepta una funcionalidad autónoma, admite la poesía como una esencia en sí misma (García, 2002; 2006; 2012; Rodríguez, 2012; Torres Salinas, 2017: 113-116).

Además de exentar al discurso poético de esa responsabilidad histórica, Sartre instaura otro matiz revelador. La vinculación entre el escritor y su obligación ética (como tal) viene dada por la "singularidad" que corresponde a cada "situación en su época". Y de aquí que Lechner señale que "en cada época el compromiso se constituye de forma distinta". Este planteamiento refuerza uno de los pilares básicos para entender el compromiso poético español en tanto en cuanto esa falsa

\footnotetext{
23 Remitimos al capítulo que abre El compromiso en la poesía española del siglo XX (1968) bajo el título de "Literatura comprometida: el término y los problemas que origina" (9-21).
} 
creencia sobre la dialéctica responsabilidad / irresponsabilidad como una toma de decisión voluntaria establece la provisionalidad de forma inherente a dicha actitud. Es decir, Sartre retoma el pulso y da continuidad al humanismo que Malraux y Gide defienden en el Primer Congreso Internacional de Escritores en Defensa de la Cultura (1935) y, posteriormente, se reafirma en la Ponencia Colectiva del II Congreso de Escritores Antifascistas (1937): la libertad creadora cómplice con el custodio de aquellas categorías trascendentales (la Razón, el Hombre, la Libertad, el Espíritu Humano, etc.) que el ascenso del fascismo había puesto en peligro.

Pero, en cualquier caso, si el propósito es rastrear los primeros pasos del compromiso poético contemporáneo en nuestro país conviene hacer un alto en la vanguardia española, así como poner en cuestión algunas premisas dadas por ciertas en torno a aquello que forma parte del estudio del veintisiete. Y en esta línea viene trabajando durante varios años el profesor Miguel Ángel García (2001; 2016a), advirtiendo que es cada vez más necesario -para historizar el compromiso poético en la España de entreguerras y, diríamos más, sus consecuencias en la escritura posterior- revisar los esquemas tradicionales de la trayectoria del veintisiete. Si la historiografía poética española reciente se encuentra trillada, como diría Pozuelo Yvancos, de mucha ira y poco estudio quizá se deba -en gran medida- a la automatización del método generacional (Rodríguez, 1984: 245-252) y la conciencia historiográfica (cfr. Bozal, 1973 (II): 119-121; Árbol y Olalla, 1993) como herencia, justamente, del veintisiete. Tanto uno como otro término ponen al descubierto la raigambre burguesa de la vanguardia española: es decir, el asentamiento generacional del veintisiete remite a una estrategia encabezada por Ortega y Gasset con el propósito de constituir la razón burguesa (Soria Olmedo, 1988: 9-28; García, 2016a: 47).

O dicho de otro modo, la institucionalización del veintisiete como vanguardia poética entre los años veinte y treinta mediante la aceptación (de ahí la conciencia historiográfica, como posicionamiento de clase) de una tarea política y cultural (una burguesía liberal que pretende modernizar la sociedad española) trae consigo la legitimación autónoma de la poesía en tanto en cuanto otorga validez a la deshumanización (y las formas puras) como lenguaje esencial y expresivo de ese Espíritu Humano, condenándolo - hasta nuestros días- a una oposición alterna y enfrentada a los contenidos, la comunicación y la urgencia (el compromiso). Aunque, por el contrario, ya sabemos que la ideología de la pureza jamás se produce materialmente al margen de la política y la historia, al margen de la vida. Así pues, el mejor camino para desarticular las etapas estandarizadas de la vanguardia poética española consiste en preguntarse por el signo ideológico de la ideología pura o deshumanizada (García, 2016a: 47-50). Y, en definitiva, caer en la cuenta de que la vanguardia española ha puesto los "signos" en el "mapa" poético español (García, 2001: 29-41) y, sus coordenadas, han regido el género durante buena parte del siglo XX y el breve camino que hemos trazado del XXI.

La polarización pureza / compromiso no solo arranca desde la creencia autónoma de la poesía, del mismo modo que envuelve a las "formas puras" bajo el mito de la objetividad deshumanizada (años veinte) hace lo propio con el otro extremo de la cuerda, una idea del compromiso amortizada en el contenido y la rehumanización temática (años treinta). ${ }^{24} \mathrm{Nada}$ más y nada menos que dibujar con trazo grueso en la piel de los poetas un círculo de tiza idealista

${ }^{24}$ Cfr. Cano Ballesta (1972). 
donde disputarse -desde hace casi un siglo- su hegemonía estética, tirando hacia un lado u otro de los márgenes. Por lo tanto, la categoría de poesía pura no ejerce un aislante seguro ante cualquier contaminación de la sociedad como el compromiso no garantiza un posicionamiento ideológico. ${ }^{25}$ Según la lectura escolástica del veintisiete, los acontecimientos históricos (Primo de Rivera, II República y Guerra Civil) y la supuesta ruptura o contradicción que representa la rehumanización surrealista propician el nacimiento de aquello que Juan Carlos Rodríguez (1984: 281-316) ha denominado "el mito de la poesía comprometida".

Tengamos presente que el agotamiento de la poesía pura (y, en consecuencia, la tutela de Ortega) viene acompañado por una situación política convulsa a nivel europeo (el capitalismo y las democracias se tambalean) que provoca una imagen de crisis en la literatura, al mismo tiempo que se recrudecen los debates sobre el compromiso artístico se pone de moda, entre los escritores, la opción del compromiso. Sin embargo, bajar a la calle, comprometerse con la urgencia histórica y vestirse las calzas y el jubón no era más que interrumpir coyunturalmente la tarea esencial de la poesía. Así, la ideología frentepopulista invitaba a los poetas a sumarse a la defensa del espíritu occidental y la verdad racionalista, a la defensa del Arte (autónomo y ahistórico) con mayúsculas. Finalmente, romper ese (según Arconada) "idilio de los poetas con las musarañas" suponía, simplemente, interrumpir la libertad creadora debido al desorden impuesto por aquella urgente gramática necesaria de la que hablaba Rafael Alberti.

La naturalización de este desarrollo lineal de la vanguardia española ha tenido unas consecuencias incalculables para las siguientes generaciones de poetas españoles. Que la "literatura entrara en guerra" (Salaün, 1985: 10) jamás puso en duda la tradicional ideología burguesa del artista o del escritor (Rodríguez, 1984: 288). Y, por consiguiente, hace imposible esa lectura del veintisiete sujeta a la evolución entre dos polos opuestos o contradictorios (por el contrario, la inversión de una problemática ideológica) que pone en juego la distinción kantiana entre pureza trascendental e impureza empírica (García, 2001: 33; 2016a: 265). Asimismo, este planteamiento determinista, plano y unívoco a la hora de estudiar la vanguardia española ha favorecido la automatización de la guerra como una bisagra o fractura, cuando -en verdad- se produce una continuidad en el marco ideológico de la poesía de posguerra (Valero Gómez, 2016a: 70) que en el ámbito estético obtendrá sus resultados en la rehumanización existencialista de la poesía social y en el asentamiento de ese mismo humanismo de fondo.

Podría decirse, en suma, que por influjo del historicismo hemos aprendido a estudiar la poesía española contemporánea a golpe de cortes y fracturas -por fragmentos periódicos y epocales-, siempre supeditados a esa falsa dialéctica que confronta la pureza de la poesía a su compromiso con la realidad social. Para los poetas del medio siglo, y buena parte de la primera generación de posguerra, la dura realidad del franquismo supuso la misma urgencia histórica para bajar a la calle que la II República y la Guerra Civil española fueron para los poetas del veintisiete. Una vez superada esa poesía oficial/religiosa que fraguará en neoclasicismo, la apertura neorromántica y el aliento existencialista teñirán los poemas de una preocupación humana que centrará las disputas durante las dos décadas siguientes a la finalización de la guerra. En este sentido, la Antología consultada (1952) de Francisco Ribes es un buen ejemplo para observar la

\footnotetext{
25 Porque, como nos recuerda el profesor Miguel Ángel García (2016a: 60), "no existen poéticas puras o impuras sino el funcionamiento objetivo de la poesía en una coyuntura histórica determinada".
} 
vigencia de esa excepcionalidad estética que exige la historia y que tomará cuerpo, años después, bajo el nombre de poesía social. Como es sabido, la instalación del eje conocimiento / comunicación vertebra la consolidación de la segunda promoción de poetas de posguerra gracias a las nuevas directrices del compromiso que Castellet fija en Veinte años de poesía española (1960): un realismo histórico y crítico que sustituya al simbolismo hasta entonces dominante (Torres Salinas, 2017: 118-120).

Dejando de lado que el propio Castellet (1960: 102-103) admite la ambigüedad y complejidad del término poesía social, es más interesante la canalización del compromiso mediante la unicidad temática del "hombre histórico" (pues atisba el formalismo temático que algunos coetáneos critican), la llamada dramática de un mundo en transformación y la voluntad programática. Ya no se trata de bajar a la calle y romper todos los versos, puesto que nos encontramos -nuevamente- ante un elenco de poetas que escriben desde una conciencia historiográfica (el realismo) que siempre arranca de una intimidad abierta a lo colectivo, de un humanismo comprometido con clara ascendencia en el engagement sartreano y que jamás interroga a la poesía en el callejón oscuro de su pretendida autonomía funcional. Tanto Poesía última (1963) de Francisco Ribes como Poesía social española contemporánea (1965) de Leopoldo de Luis son dos antologías que marcan el paso a la hora de concluir que sobre el confortable colchón de la participación (Claudio Rodríguez), la actitud moral (Ángel González), la exigencia histórica (Sahagún) y la experiencia creadora (Valente) queda resguardada -límpida y reluciente sobre su vitrina- la esencia trascendental de la poesía. O como señala Leopoldo de Luis (1965: 181-215) en las "notas" de su antología, la poesía social es un "fenómeno de nuestro tiempo" que "responde a una actitud frente a la sociedad" que "se alza contra una situación que considera injusta": finalmente, "una conciencia puesta en pie".

Pese a tratarse de dos coyunturas históricas diferentes, será fácil apreciar que no existe mucha diferencia entre los parámetros que rigen el compromiso de la vanguardia con aquellos que van depurándose a lo largo de la posguerra. Si por un lado la responsabilidad, urgencia y provisionalidad empuja a los poetas a rebajarse o degradarse; por otro lado, se preocupan decididamente en aunar intimidad y compromiso para no poner en peligro la imagen humanista del arte. No será tan descabellado pensar, entonces, que la homogeneidad estética y moral que se atisba desde (aproximadamente) 1930 hasta los últimos años de la posguerra (Mainer, 1989: 8) manifiesta la continuidad de un humanismo burgués que sigue haciendo a los poetas pensarse dentro de ese círculo de tiza -casi insalvable- que ciñe en corto la pureza y el compromiso como parte de un mismo óbice. Sin embargo, tras la irrupción de la estética novísima en los últimos estertores del franquismo y una vez completado el tránsito democrático en la sociedad española se vislumbra una inflexión decisiva en el panorama poético que atañe a un concepto como el de compromiso que -ingenuamente- se juzgaba ya cerrado.

A la hora de aproximarse al estudio de la poesía española finisecular y su paso al siglo XXI se ha consolidado en la historiografía literaria el solapamiento de la idea de normalización democrática sobre una normalización poética. Y, como podrá imaginarse, esta perspectiva incide directamente sobre un posible análisis del compromiso poético de unas décadas a esta parte. Será -de nuevo- Lechner (1968: 6) quien nos advierta a la altura de 1968, apenas tres años más tarde de la defunción oficial de la poesía social, la existencia de un gran vacío en el campo científico 
sobre la poesía española comprometida. Y, de algún modo, el tiempo ha venido a darle la razón, ya que junto a la revitalización cívica y moral que ha vivido nuestra poesía durante los últimos treinta años, también ha visto la luz una serie de trabajos imprescindibles para desagraviar esta cuestión. (Pensamos, entre muchos otros, en el loable esfuerzo de investigadores como Araceli Iravedra, Luis Bagué Quílez o Miguel Ángel García). Pese a ello, se hace sentir el "profundo desencuentro" existente -metidos ya en el milenio nuevo- entre el canon "general" y el canon "parcial" del compromiso (Iravedra, 2017a: 218), como pueden ser buenos ejemplos los panoramas críticos trazados en las antologías más recientes (Martín Gijón, 2017: 219-220).

Además, plegar sobre un mismo plano (la normalización) dos realidades como la poética y la socio-política deja al descubierto algunos signos importantes que podemos responder con la ayuda de las siguientes preguntas: 1) ¿qué o quién lleva a cabo, poéticamente hablando, esa normalización?; y 2) ¿qué es exactamente aquello que se normaliza? Ocupándonos de la primera de ellas, por respetar cierta higiene expositiva, el afianzamiento de la democracia española está representado (y no es casual el término) por la llamada poesía de la experiencia, conocida por sustentar el cetro de la hegemonía poética durante -casi- los últimos veinte años del siglo pasado más algunos cursos de la presente centuria. Tanto es así que, como sabemos, la poesía de la experiencia ha cuajado como nuevo paradigma estético durante los años ochenta y noventa colocándose, rápidamente, en el disparadero de las críticas. Aunque las etiquetas y las ansias globalizantes pueden ser tentadoras, debe considerarse que del mismo modo que la relectura del compromiso poético realizada en el cambio de siglo no es homogénea (Iravedra, 2010: 82), en cuanto que hay vida más allá de la experiencia, tampoco es todo adhesión social e impulso análogo (más bien plural) lo que reluce bajo el marbete experiencial (Bagué, 2004: 12; 2006: 51; Lanz, 2008: 41).

Tras el agotamiento del modelo sesentayochista a finales de los años setenta, cobra fuerza un nuevo impulso formado (entre otros) por tres jóvenes granadinos (Álvaro Salvador, Javier Egea y Luis García Montero) que cuentan con el respaldo teórico del profesor Juan Carlos Rodríguez. La otra sentimentalidad se muestra en sociedad con un libro-manifiesto de idéntico nombre publicado en el año 1983 y un poemario sobre las espaldas de cada uno de los integrantes. El propósito inicial de la otra sentimentalidad no era otro que poner en jaque la noción tradicional de poesía (y, matando dos pájaros de un tiro, la de compromiso) cuestionando su sentido expresivo (a cambio de la representación) y el sujeto poético burgués mediante una escritura materialista. De ahí que, en un principio, quieran reinventar el género afirmando que "la poesía miente" o que "un sujeto expresado es un sujeto oprimido". Poco tiempo duraría, según opinión de Juan Carlos Rodríguez (1999a: 41-43), los presupuestos radicalmente marxistas de la otra sentimentalidad, puesto que hacia la mitad de la década sus postulados empezaban a "confluir" en la poesía de la experiencia. ${ }^{26}$ Fueron muchas las cosas que se dejaron en el camino ante la dificultad de enfrentarse a la práctica ideológica, pero tampoco ayudaron la recepción errónea que recibió su defensa de Gil de Biedma como ejemplo de otra experiencia posible con la poesía (García, 2002: 17) y una crítica que siempre partía de un sujeto previo (Rodríguez, 1999a: 29).

${ }^{26}$ Cfr. Wahnón (2003) y d’Ors (1994). 
Todavía entre 1982 y 1983, cuando su genuino azote se mantenía firme, hablar de experiencia -para la otra sentimentalidad - se situaba al margen de esa sofística polarización (pureza frente a compromiso) cómplice con las reservas trascendentales de la poesía (García, 2002: 17). Pero, como insistimos, la absorción de la otra sentimentalidad por parte de la poesía de la experiencia comporta la validación del realismo como nuevo territorio de la disputa historiográfica desde diferentes ópticas estéticas, pero respetando unos lazos inamovibles (autobiografía, ficción del género, magisterio del 50, etc.) que restaban importancia al cuestionamiento ideológico de la poesía en sí misma en favor de un relato íntimo de la nueva vida democrática-capitalista (Rodríguez, 1999a: 50; 1999b: 257; García, 2002: 18; Bagué, 2006: 114; Lanz, 2008: 41; Iravedra, 2010: 31). Dicho con otras palabras: si la otra sentimentalidad se enfrenta al pacto confesional de la imagen poética moderna, la poesía de la experiencia -por el contrarioreafirma la operatividad ideológica de esa misma imagen reduciendo los esfuerzos de los granadinos al pistoletazo de salida de un proceso rehumanizador que culmina con la firma de un pacto realista, tanto como la reprivatización de la intimidad lírica (Sánchez Zamarreño, 1989: 59; Mainer, 1994: 153-154; Juaristi, 1994; Lanz, 1994: 5).27

Así se entiende que la poesía de la experiencia fuera vista por muchas voces bajo el disfraz de definitiva, una invocación del ethos fukuyamiano que no solo significó poner el compromiso al pie de los caballos (con algunas remodelaciones fundamentales sobre su viejo mito, como ahora veremos), sirvió también para que -ingenuamente- el realismo pasara a representar la democracia misma. Y en este sentido, Luis García Montero se ha convertido en cabeza visible de la poesía de la experiencia siendo destinatario de durísimos ataques. A decir verdad, y a pesar de los límites que el poeta granadino siempre procura señalar en el término experiencia, existe un componente en su propuesta que se encuentra a medio camino entre el riesgo ${ }^{28}$ y la incomprensión. ${ }^{29}$ De poco han servido sus esfuerzos a la hora de matizar su distancia con respecto al sujeto lírico contemporáneo, el perímetro de la normalización y la poesía para seres normales, así como el

\footnotetext{
27 Todavía hoy se sigue cayendo en el error de aglutinar bajo un mismo marbete la otra sentimentalidad y la poesía de la experiencia, cuando acabamos de ver que son proyectos con una finalidad ética-estética completamente disímil.

${ }^{28}$ Y estos riesgos no solo vienen del lado de los reproches y críticas más feroces. Parte de culpa se encuentra en la legitimación de una lectura en positivo. Por ejemplo, si se interpreta que la poesía para seres normales "significa pactar democráticamente con las condiciones objetivas del sistema" (Gracia, 2001: 61).

${ }^{29}$ En cualquier caso, tanto este riesgo como esta incomprensión no están sujetas a la inocencia literaria como bien puede leerse en un pasaje inolvidable de José-Carlos Mainer (1994: 168): "No sería extraño en todo caso porque García Montero, como otros muchos, carece de inocencia literaria pues es poeta-profesor. Nunca ha habido tantos de ese género como ahora y fuera quizá más corto establecer la nómina de los profesores de literatura que no escribimos versos que la más nutrida de quienes los escribe y excelentes, aunque no todos ostentan la maestría de los citados poetas granadinos, de Guillermo Carnero, Andrés Sánchez Robayna, Jaime Siles y Jenaro Talens, entre otros. Los nuevos poetas -sean profesores o no- conocen de primera mano los entresijos de la semiótica, han leído la tradición remota y próxima con mirada crítica, saben de la historia que les ha tocado vivir. Por eso, sus personajes interpuestos, sus héroes literarios, están caracterizados por la ausencia de inocencia, una condición que sobrellevan con una mezcla de ironía y autoconmiseración".
} 
diálogo sobre la utilidad / inutilidad de la literatura. ${ }^{30}$ De hecho, pronto salieron al paso reacciones encontradas, incluso desde dentro de la otra sentimentalidad, ${ }^{31}$ que empezaron a poner en duda las posiciones acomodaticias de la experiencia mediante una eclosión desperdigada de propuestas (no necesariamente comprometidas al uso) que recorren el más estricto humanismo (poesía entrometida de Fernando Beltrán), el desconsuelo y la poesía practicable (Jorge Riechmann), el realismo sucio (Roger Wolfe, David González, Pablo García Casado, etc.) o la oposición militante (Alicia Bajo Cero) y férrea (Voces del Extremo). Si la poesía de la diferencia aglutinó una primera oposición a la poesía de la experiencia recién comenzada la década de los noventa, ahora es la conciencia crítica, compartimento teórico algo frágil y amenazado por el desbordamiento, quien colectiviza esta alternativa.

El escenario poético español de los últimos treinta años ha reformulado el compromiso desde distintos ángulos estéticos e, incluso, como una opción inicial que marque toda una producción textual, ajena a la urgencia y la exigencia histórica. Este pequeño giro con respecto a la concepción primitiva del compromiso poético español y el engagement sartreano rompe, sin lugar a dudas, las barreras de la provisionalidad estética en aras de una responsabilidad ética-moral que ya no es opcional, sino que se incorpora como un derecho y un deber del contrato social-poético. Es decir, la cacareada hasta la saciedad normalización poética de este país venía a ser la normalización del compromiso poético: algo asi como el paso decisivo del mito a la normalización del compromiso en nuestra historiografía poética reciente. De tal manera que si la democracia había elevado el capitalismo a la categoría de vida normal podía entenderse como lógica la creciente respuesta ética de los poetas ante la realidad. Basta con leer unas palabras cardinales de Leopoldo de Luis, a la sazón gran partícipe y testigo en este asunto, cuando en una entrevista a propósito de su premio Nacional de las Letras (El Mundo, 2003) declara sobre la poesía que es la "expresión más íntima y verdadera del género humano" y que "se sigue haciendo poesía social [entiéndase también comprometida] porque no es una moda sino un modo". Pasando de largo por la manida alusión al esencialismo poético, la segunda parte es decisiva porque confirma la naturalización del compromiso como una carta más al servicio de esa baraja humanista de la poesía: dentro de la sagrada ecuación burguesa que conserva intacta la imagen de sí misma, su pureza y esencialidad. ${ }^{32}$

Así, del mismo modo que la explotación y la dominación ideológica parece ocultarse tras una cortina de humo que llamamos vida (y nos ofrece la posibilidad de ser libres y participar en la sociedad); la poesía ha reafirmado su falsa función autónoma instaurando definitivamente la denuncia y la crítica como una característica específica de la civilización moderna (Foucault, 2003:

\footnotetext{
30 Cfr. García Montero (1994; 2000; 2002). Son pocas las reacciones o respuestas explícitas del propio García Montero a tales ataques, tras verse situado en el ojo del huracán. En todo caso, destacamos dos ejemplos. Por un lado, en su citado artículo "Una musa vestida con vaqueros" (1994), cuando declara que "hay una parte mezquina y poco significativa en estas críticas, una acalorada colección de rabietas que proviene de las envidias al uso"; y, por otro lado, en "El oficio como ética" (2000), el poeta granadino dice haber cometido "la imprudencia de esperar que para interpretar mi poética se tomarían la molestia de leer mis libros y no tuve miedo de que la normalidad aludida se entendiese como una defensa de los valores establecidos o como una negación de la disidencia".

31 Cfr. Salvador (1994).

32 Es sabido que el sueño de la razón poética produce monstruos.
} 
5). Cuanto más gritas menos te oyen. ${ }^{33}$ Hoy el compromiso poético, si quiere enfrentarse de veras al horizonte ideológico de producción que le atenaza desde hace siglos, únicamente pasa por cuestionar el propio compromiso poético, ponerlo bajo sospecha, hasta alcanzar -como plantea Althusser (1962) - un inconsciente a cielo abierto. Aquello que impide el cuestionamiento radical del propio capitalismo es la creencia en la forma democrática de la lucha contra el capitalismo, como ha dicho Žižek (2011: 190) inspirándose en una conocida afirmación de Alain Badiou ("Hoy día, el enemigo no se llama Imperio o Capital. Se llama Democracia"). La clave sigue radicando allí mismo: en la identificación que la sociedad civil lleva a cabo con las convenciones de libertad y democracia. Su violencia se ha vuelto sistémica (anónima y objetiva) y la amenaza "no es la pasividad, sino la pseudoactividad, la necesidad de ser activo, de participar, de enmascarar la vacuidad de lo que ocurre" (Žižek, 2009: 255): la individuación del yo que nos empuja a decir yo-soy-libre (Rodríguez, 2002). Y el compromiso poético tiene mucho que ver con esa participación activa de la que habla Žižek cuando asegura que "lo más difícil es dar un paso atrás, sustraerse”. Tal vez ya no sea un problema terminológico. (Llámese social, comprometida o crítica). Tampoco de abandonar las categorías de la estética de consumo y su juicio crítico basado en el esoterismo de un vocabulario cómplice de tantas otras cosas. ${ }^{34}$ Más bien consiste en descomprometerse de toda esa producción material de la vida. Por mucho que la poesía comprometida siga atrapada en algunas de sus contradicciones originales (Bagué, 2016: 118) enarbolando el designio cívico como seña de identidad (Iravedra, 2017b: 262), posiblemente, siga mereciendo la pena vivir en ese pequeño pueblo en armas contra la soledad. Aunque -a vecesolvidamos que la historia, igual que ocurre con las naciones, deja indefensos a los individuos

\footnotetext{
33 Existe un viejo chiste soviético surgido tras la muerte de Stalin que venía a reproducir (en los siguientes términos) la conversación entre dos ciudadanos de la URSS: “¿Te has enterado de la muerte de Stalin?”, "Sí, ¿y ahora quién se lo dice a Stalin?". Algo parecido ocurre con el tema del pensamiento crítico y que -lógicamente- se relaciona directamente con la poesía comprometida. Porque si la literatura (hemos dicho) no existe más que en el espejo de nuestro inconsciente ideológico, ¿qué importa querer cambiar las piezas de juego de la norma literaria si, finalmente, el tablero donde se batalla continúa siendo el mismo (esa norma literaria impuesta y no otra)? O por decirlo con palabras de Juan Carlos Rodríguez, el inconsciente ideológico es la piel que tenemos; en tanto que configura la lógica interna y la objetividad de los textos. Y cuando hablamos de una ruptura en la provisionalidad del compromiso, excusa indispensable (hasta hace bien poco) para degradar el discurso poético, estamos recalcando que el pensamiento crítico es un invento burgués. Y, por tanto, no responde a una "función subordinada" en relación con lo que constituye la literatura (o la filosofía, la moral, el derecho, la ética, etc.), como ha dicho Foucault (2003: 5), sino que forma parte de la funcionalidad ideológica misma sobre la que -materialmente- se produce, precisamente, la literatura (o la filosofía, la moral, el derecho, la ética, etc.). Tanto como pasar por el filtro del tema poético una hipóstasis estética. El problema continúa siendo - como señala Marx- que las categorías remiten a formas de ser, a formas de existencia. Puede ser que (aquello que se entiende por) la "toma de conciencia" se haya convertido en un "acto cívico" (García Montero, 2002: 15), donde la misión del intelectual sea "ayudar al [supuesto] triunfo racional e ilusionado de las nuevas conquistas de la democracia" (Cano Ballesta, 2007: 19). Pero la confrontación con este "sistema" de vida se presenta bajo nuevas formas de socialización proporcionadas por el enemigo (Mainer, 2001: 5). O volviendo al chiste sobre Stalin, será difícil cuestionarnos una práctica ideológica real de la poesía comprometida sin antes poner en duda las propias señas de identidad del capitalismo (Rodríguez, 2013: 64), las propias señas de identidad de la categoría de compromiso. De ahí que los poetas se hayan replanteado, durante las últimas décadas, su actitud cívica (Bagué, 2004: 14) a raíz de estas nuevas formas de socialización (ecologismo, feminismo, cuestiones de género, derechos de los animales, etc.) más la oportunidad que se presenta ante el devenir histórico (poesía indignada, $11 \mathrm{M}, 15 \mathrm{M}$, Tercer Mundo, Oriente Medio, etc.). No se trata tanto de plantearse (como hace Celaya en 1952 mediante el altavoz que supone la antología de Ribes) si la poesía debe situarse dentro o fuera de la historia, sino más bien si la poesía puede (y cómo) producirse en una historia otra.

34 Althusser (1995) nos enseña que la subjetividad de la creación es el reflejo especular de la subjetividad del consumo.
} 
impidiéndonos atacar (Marx, 1970: 33): como todavía resuenan en nuestras (in)consciencias aquellos versos pertenecientes a los últimos días de Miguel Hernández, "pero hay un rayo de sol en la lucha / que siempre deja la sombra vencida". 


\section{BIBLIOGRAFÍA}

ADORNO, Theodor W. (2009). "Compromiso". Notas sobre literatura. Obra completa. vol. 11. Madrid: Akal: 393-413.

Althusser, Louis. “Devant le surréalisme: Alvarez-Rios”. Lettres françaises 954 (1962).

Althusser, Louis (1968). La filosofía como arma de la revolución. Madrid: Siglo Veintiuno. 2008: 26a ed.

Althusser, Louis (1995). "Cremonini, peintre de l'abstrait". Écrits philosophiques et politiques (II). Stock / IMEC: París: 596-597.

Árbol, Carlos E. del y Olalla Real, Ángela (1993). "Maruja Mallo, entre la tradición y la vanguardia”. Cuadernos Hispanoamericanos 514-515 (1993): 293-300.

BAgUÉ QuílEZ, Luis (2004). "Entre clasicismo y vanguardia: el compromiso poético en los autores de los años ochenta". Anales de literatura española 17 (2004): 11-34.

Bagué Quílez, Luis (2006). Poesía en pie de paz: Modos del compromiso hacia el tercer milenio. VI Premio Internacional Gerardo Diego de Investigación Literaria. Valencia: Pre-Textos / Fundación Gerardo Diego.

BAguÉ Quílez, Luis (2016). "La pesadilla que se muerde la cola: antologías poéticas del compromiso en el cambio de siglo”. GARCía (2016b): 103-119.

BALIBAR, Renée (1974). Les français fictifs. Le rapport des styles littéraires au français national. Hachete: París.

BARTHES, Roland (2005). El grado cero de la escritura seguido de Nuevos ensayos críticos. Madrid: Siglo XXI.

BozAL, Valeriano (1973). Historia del Arte en España. Madrid. Istmo. II vols.

BRECHT, Bertolt (1970). Escritos sobre teatro. Buenos Aires: Nueva Visión.

CANO BALLESTA, Juan (1972). La poesía española entre pureza y revolución (1930-1936). Gredos: Madrid.

CANO BALLESTA, Juan (2007). Nuevas voces y viejas escuelas en la poesía española (1970-2005). Granada: Atrio.

CASTELleT, J. M. (1960). Veinte años de poesía española (1939 - 1959). Barcelona: Seix Barral.

D’Ors, Miguel (1994). En busca del público perdido. Aproximación a la última poesía española joven (1975-1993). Impredisur: Granada.

DERRIDA, Jacques (1989). La escritura y la diferencia. Barcelona: Anthropos.

Eagleton, Terry (2011). Por qué Marx tenía razón. Barcelona: Península.

EL Mundo (2003). "Leopoldo de Luis, premio Nacional de las Letras". El Mundo (12 de diciembre de 2003): 2. 
FOUCAUlT, Michel (1971). Las palabras y las cosas. Una arqueología de las ciencias humanas. México: Siglo XXI.

FOUCAULT, Michel (2003). Sobre la Ilustración. Madrid: Taurus.

GARCíA, Miguel Ángel (2001). El Veintisiete en vanguardia. Hacia una lectura bistórica de las poéticas moderna y contemporánea. I Premio Internacional Gerardo Diego de Investigación Literaria. Valencia: Pre-Textos / Fundación Gerardo Diego.

GARCíA, Miguel Ángel (2002). "Literatura e Historia en la otra sentimentalidad (O cómo poner a la poesía en un compromiso)". Iravedra (2002): 16-18.

GARcíA, Miguel Ángel (2006). "Y casi por compromiso. Consideraciones sobre poesía actual y política”. Paraíso. Revista de poesía 1(2006): 25-35.

GARCíA, Miguel Ángel (2012). La literaturay sus demonios. Leer la poesía social. Madrid: Castalia.

GARCíA, Miguel Ángel (2015). "Las cuatro albertianas y la desmitificación del compromiso". García, Miguel Ángel; Olalla, Ángela y SORIA Olmedo, Andrés (eds.). La literatura no ha existido siempre. Para Juan Carlos Rodríguez. Granada: Universidad de Granada: 227-237.

GARCíA, Miguel Ángel (2016a). Cartografías del compromiso. Vanguardia e ideología en los poetas del 27. Barcelona: Calambur.

GARCíA, Miguel Ángel (ed.) (2016b). "A la ética por la estética. Canon, compromiso poético y antologías en España (siglos XX-XXI)”. Anthropos 245 (2016).

GarCíA, Miguel Ángel (ed.) (2017a). El compromiso en el canon. Antologías poéticas españolas del uiltimo siglo. Valencia: Tirant lo Blanch.

GARCíA, Miguel Ángel (ed.) (2017b). El canon del compromiso en la poesía española contemporánea. Antologías y poemas. Madrid: Visor.

García Montero, Luis (1983). "La otra sentimentalidad”. El País (8 de enero de 1983): 7-8.

GArCÍA Montero, Luis (1994). “Una musa vestida con vaqueros”. Ínsula 565 (1994): 24-25.

García Montero, Luis (2000). "El oficio como ética". Romera Castillo, José y Gutiérrez Carbajo, Francisco (eds.). Poesía histórica y (auto)biográfica (1975-2000). Madrid: Visor: 87-104.

García Montero, Luis (2002). Poesía, cuartel de invierno. Barcelona: Seix Barral. $2^{\mathrm{a}}$ ed.

GRACIA, Jordi (2001). Hijos de la razón. Contraluces de la libertad en las letras españolas de la democracia. Barcelona: Edhasa.

GramsCI, Antonio (1977). Cultura y literatura. Barcelona: Península.

HAusER, Arnold (1976). Historia social de la literatura y del arte. Madrid: Guadarrama. III vols.

IRAVEDRA, Araceli (coord.) (2002). “Los compromisos de la poesía”. Ínsula 671-672 (2002).

IraVedra, Araceli (2010). El compromiso después del compromiso. Poesía, democracia y globalización (poéticas 1980-2005), Madrid: UNED.

IrAVEDRA, Araceli (2017a). “Au-dessus de la mêlée? Compromiso, canon y antologías poéticas en la escena del posfranquismo”. GARCÍA (2017a): 183-224. 
IRAVEDRA, Araceli (2017b). "Feroces o la provocación de lo real: en busca de un canon del compromiso". GARCÍA (2017b): 261-285.

JimÉnez Millán, Antonio (1984). Vanguardia e ideología. Aproximación a la bistoria de las literaturas de vanguardia en Europa (1900-1930). Málaga: Universidad de Málaga.

JUARISTI, Jon (1994). "El pacto realista”. Ínsula 565 (1994): págs. 25-26.

KRISTEVA, Julia (1978). Semiótica 1. Madrid: Fundamentos. 2001: $4^{a}$ ed.

LANZ, Juan José (1994). "Primera etapa de una generación: notas para la definición de un espacio poético: 1977-1982”. Ínsula 565 (1994): 3-6.

LANZ, Juan José (2008). "Luces de cabotaje: la poesía de la Transición y la generación de la democracia en los albores del nuevo milenio". Monteagudo 13 (2008). Monográfico Poesía española del siglo XXI coordinado por Francisco J. Díez de Revenga y Luis Bagué: 25-48.

LeChner, J. (1968). El compromiso en la poesía española del siglo XX. Parte Primera. De la generación de 1898 a 1939. Leiden: Universitaire Pers Leiden.

LuIS, Leopoldo de (1965). Poesía social española contemporánea. Antología [1939-1968]. Edición de Jorge Urrutia y Fanny Rubio. Madrid: Biblioteca Nueva. 2001: $4^{a}$ ed.

LUKÁCS, Georg (1975). Historia y conciencia de clase. Barcelona: Grijalbo.

MACHEREY, Pierre (1974). Para una teoría de la producción literaria. Venezuela: Universidad Central de Venezuela.

MAINER, José Carlos (1989). La corona hecha trizas (1930-1960). Barcelona: PPU.

MAINER, José Carlos (1994). De postguerra (1951-1990). Barcelona: Crítica.

MAINER, José Carlos. "Globalización o apocalipsis: de las maneras de entenderlo". Poesía en el campus 49 (2001): págs. 3-7.

MARTín Gijón, Félix (2017). “Un octubre nuevo. Canon, compromiso y 1917 versos”. García (2017b): 219-243.

MARX, Karl (1970). La guerra civil en Francia. Madrid: Editorial Ricardo Aguilera. 1976: $4^{\mathrm{a}}$ ed.

MARX, Karl y ENGELS, Friedrich (2014). La ideología alemana. Crítica de la novísima filosofía alemana en las personas de sus representantes Feuerbach, B. Bauer y Stirner, y del socialismo alemán en las de sus diferentes profetas. Madrid: Akal.

RodríGueZ, Juan Carlos (1984). La norma literaria. Madrid: Debate. 2001: $3^{\text {a }}$ ed.

RoDríGuEZ, Juan Carlos (1994). Lorca y el sentido. Un inconsciente para una historia. Madrid: Akal.

Rodríguez, Juan Carlos (1999a). "Acerca del origen de este libro o This Side of Paradise". Dichosy escritos. (Sobre La otra sentimentalidad y otros textos fechados de poética). Madrid: Hiperión: 19-55.

RoDríGueZ, Juan Carlos (1999b). "La poesía y la sílaba del no (Notas para una aproximación a la poética de la experiencia)". Dichos y escritos. (Sobre La otra sentimentalidad y otros textos fechados de poética). Madrid: Hiperión: 245-290. 
RodRíGueZ, Juan Carlos (2002). "El yo poético y las perplejidades del compromiso". Iravedra (2002): 53-56.

RoDRÍGUEZ, Juan Carlos (2005). "Lectura y educación literaria”. NúÑEZ RUIZ, Gabriel y CAMPOS FERnÁNDEZ-FÍGARES, Mar. Cómo nos enseñaron a leer. Madrid: Akal: 5-50.

Rodríguez, Juan Carlos (2013). De qué hablamos cuando hablamos de marxismo. Madrid: Akal.

RodríGuez, Juan Carlos (2015). Para una teoría de la literatura. (40 años de historia). Madrid: Marcial Pons.

SALAÜN, Serge (1985). La poesía de la guerra en España. Madrid: Castalia.

SALVADOR, Álvaro (1994). "Con la pasión que da el conocimiento: notas acerca de la llamada otra sentimentalidad”. Zurgai (1994): 44-49.

SÁNCHEZ ZAMARREÑO, Antonio. "Claves de la actual rehumanización poética”. Ínsula 512-513 (1989): 59-60.

SARTRE, Jean-Paul (1976). ¿Qué es la literatura?. Buenos Aires: Losada.

SORIA Olmedo, Andrés (1988). Vanguardismo y Crítica Literaria en España (1910-1930). Madrid: Istmo.

TORRES SALINAS, Ginés (2017). "Algunas notas sobre el compromiso en las antologías del grupo poético de los años 50”. En GARCía (2017a): 113-147.

VALERo GómeZ, Manuel (2016a). Juan Gil-Albert y la poesía española del siglo XX. XVI Premio Internacional Gerardo Diego de Investigación Literaria. Valencia: Pre-Textos / Fundación Gerardo Diego.

VALERO GÓMEZ, Manuel (2016b). "El ajedrez asolado. Acerca de la poesía española actual". Nueva poesía alicantina (2000-2015). Alicante: Instituto Alicantino de Cultura Juan Gil-Albert: 11-50.

WAHNÓN, Sultana (2003). "Lírica y ficción: de la otra sentimentalidad a la poesía de la experiencia". MORALES RAYA, Remedios (coord.). Homenaje a la profesora $M^{a}$ Dolores Tortosa Linde. Universidad de Granada: Granada: 493-510.

ŽIŽEK, Slavoj (2001). El espinoso sujeto. El centro ausente de la ontología politica: Buenos Aires: Paidós.

ŽIŽEK, Slavoj (2009). Sobre la violencia. Seis reflexiones marginales. Barcelona: Paidós.

ŽIŽEK, Slavoj (2011). En defensa de causas perdidas. Madrid: Akal.

ŽIŽEK, Slavoj (2012). Viviendo en el final de los tiempos. Madrid: Akal. 